\title{
MODIFICATION OF PORTABLE WEEDING CUTTER FOR IRRIGATION AND DRAINAGE BANKS
}

\author{
M. E. El-Iraqi ${ }^{1}$ and W. F. EL Metwally ${ }^{2}$
}

$\underline{\text { ABSTRACT }}$

The main objective of this study is to develop the cutter blade of the portable weeding cutter to increase its weeding efficiency and avoid the main problems of cutter blade damage, as well as, the labor fatigue resulting from repetitive cutter blade shocking with hard obstacles at banks of irrigation and drainage channels. The portable weeding cutter with two imported cutting blades and two modified cutting blades was evaluated for cutting three different types of weeds, namely: Diss grass, Giant reed and Cogon grass based on the cutting height ( $\mathrm{mm})$, cutting capacity, (100 $\left.\mathrm{m}^{2} / \mathrm{h}\right)$, the cutting efficiency (\%), energy requirement and weeding cost. The obtained results could be concluded as follows:

- Using the portable weeding cutter with short flying chain blades increased the cutting capacity by about 328.55, 358.19 and $348.73 \%$ and increased cutting efficiency by about 3.09, 5.26 and $7.53 \%$ comparing with manual method for cutting Diss grass, Giant reed and Cogon grass, respectively.

- The introduction of the portable weeding cutter with short flying chain blades for controlling such growing weeds on the irrigation and drainage channels banks should be promoted in order to reduce the manpower requirements (about 5-11\%) and reduce the weeding cost (about 240-265\%) that is not easily available and also to be able to concentrate weeding operation in the best period of cutting weed.

\section{INTRODUCTION}

harles et al. (2002) reported that weeds are not generally a big problem on roads, as weeds do not grow well on compacted areas and most weeds can be controlled with herbicides and mechanical removal. Weeds are far more difficult to manage on irrigation

\footnotetext{
${ }^{1}$ Senior Researcher, Agric. Eng. Res. Inst., Agric. Res. Center, Egypt

${ }^{2}$ Researcher, Agric. Eng. Res. Inst., Agric. Res. Center, Egypt
} 
structures, where water movement, and the physical size, shape and location of the structures requires management with specialized equipment. Weeds on irrigation structures are a problem because:

- They increase the expenditure on labor and equipment, render harvesting difficult, and reduce the quality and marketability of agricultural produce;

- They block the drainage/ irrigation channels and may restrict the flow of water, which in turn can reduce irrigation effectiveness, increase water logging, and can cause erosion and failure of banks;

- The dense growth of weeds in water pollutes the water because they deoxygenate the water and kill the fish;

- They can be hosts for insects/diseases and make access to channels and structures difficult and provide a habitat for snakes and other pests in areas where siphons are being set; and

- They are a source of weed seeds that contaminate irrigation water neighboring fields.

They added, the options for managing weeds on roads and irrigation structures are 1) chemical control with herbicides; 2) mechanical control with cultivators and graders, excavators and chippers; and burning.

Generally, weeds are the plants, which grow where they are not wanted. Any weed can be a problem on irrigation and drainage structures, but some species are more difficult to manage than are others. Among the more troublesome weeds are: Diss grass, Giant reed and Cogon grass which are considered the common weeds growing on channel banks.. Diss grass is a frost hardy perennial evergreen grass with cream flowers and it takes 2 to 3 years to flower. It grows well in direct sun, and prefers medium levels of water. This plant has an ultimate height of $2.8 \mathrm{~m}$ and spread of $1 \mathrm{~m}$ (Wiley Online Library, 2000). Giant reed, also known as wild cane, is a perennial grass that can grow to over 20 feet in height. Giant reed chokes riversides and stream channels, crowds out native plants, interferes with flood control, increases fire potential, and reduces habitat for wildlife (Swearingen, 2009). Cogon grass has the potential to dominate disturbed and marginal areas. The thick rhizome mass allows dense monotypic stands to become established, and also confer an 
impressive ability to spread vegetative. It thrives in disturbed and marginal habitats such as roadsides and ditches (Bennett 2006).

Giant reed is having significant impacts on the hydrology of South Africa. As the species invades South African river banks, it becomes dominant in dense, monotypic stands that replace native vegetation and decrease wildlife diversity (Van Wilgen et al., 2007). These tall stands of grass have above average water usage (based on per leaf area transpiration) which can alter stream hydrology and sedimentation, while increasing the risk of flooding (Mgidi, 2004). Additionally, giant reed can increase fire incidence and subsequently re-grows three to four times faster than native South African riparian plants, thereby ensuring its continued invasion (Coffman et al. 2004).

Fogelberg and Kritz (1999) mentioned that the interest in the use of mechanical weeders for the grown weeds at irrigation and drainage channels near crop fields has increased rapidly during recent years due to the public debate about environmental degradation and the growing demand for organically produced food. However, knowledge concerning the working principles, soil influence and weed efficacy is still limited for several of these non-chemical methods, and optimum weed control has been difficult to achieve. To fulfill these goals, several studies on mechanical weed control methods have been initiated, with the main focus on solving weed problems in irrigation and drainage channels near or beside grown vegetable crops.

Burnell et al. (2003) noticed that the mechanical weed control on hard surface areas include sweeping, brushing, hand hoeing, and on gravel surfaces, harrowing. The equipment can be tractor mounted (sweeping, brushing, harrowing) or hand-pushed machine. The mechanical methods are more effective when controlling larger weeds or renovating neglected areas, as compared with the thermal methods. Mowing and cutting can reduce seed production and restrict weed growth, especially in annuals cut before they flower and set seed. Also, the weekly mowing of cogon grass reduced the number of plants per unit area by $74 \%$ (Hanson, 1996). Shallow tillage (less than 3 in. deep), such as disking, may be effective if repeated frequently (Johnson et al. 1999). Repeated deep tillage (greater 
than 3 in. deep) may control cogon grass by inverting, burying, and exposing rhizomes but is not always possible on a row (Chikoye et al. 2000).

\section{Problem statement and objectives}

No doubt that weed control at irrigation and drainage borders and banks is one of the difficult agricultural operations and high costly at the same time. In Egypt this operation is done by arm of excavator which is driven by tractor PTO, or self-propelled excavator. Those tools are not effective in controlling weeds (clearing) due to the tree trunks and its roots spreading on these banks and large volume of these excavators. Also, it can cause severe erosions at banks and reduce areas of roadsides borders beside banks. In addition, this weed control method is too costly. On the other hand, some farmers try to use the portable weeding cutters in weed control at those banks. These tools have some advantages, such as easy to use, low purchase cost and do not cause erosion for banks. However, these tools are still not common in use and did not give good results to control weeding due to some obstacles such as hard stone, tree roots and hardness/dense weeds spreading on these banks, such as Giant reed (Arundo donax), Cogon grass (Imperata cylindrica) and Diss grass (Ampelodesmos mauritanica) which could damage cutter/blades of portable weeding cutter and produce a strong reaction on labor body from shocking with these obstacles. Cutter blade is considered the most important part of portable weeding cutters which have been directly affecting its weeding efficiency as well as being directly affected by shocking with obstacles.

Therefore, the main objective of this study is to develop the cutter blade of the portable weeding cutter to increase its weeding efficiency and avoid the main problems of cutter blade damage, as well as, the labor fatigue resulting from repetitive cutter blade shocking with hard obstacles at banks of irrigation and drainage channels. In addition, the secondary aims which can be gained are as follows;

1- Solving problems of weeds control at banks of irrigation and drainage channels. 
2- Realizing the economical objective of this study by producing an effective and cutting blades to reduce weed control cost in those banks.

3- Reducing the direct and indirect hazard effects of growing weeds on those banks.

4- Reducing environmental pollution resulting from using weed herbicides in such case.

\section{MATERIAL AND METHODS}

\section{1- Materials}

In this study, the portable weeding cutter of Zenoah-GT25N4, Japanese made (brush type) was used to drive the imported and modified blades under study. The blade modification process was done at some private workshop in Damanhor city, Egypt. However, the evaluation experiments were carried out at Rice Mechanization Center, Agri. Eng. Res. Institute through cutting the most common growing weeds on irrigation/drainage channel banks of RMC farm.

\section{1-1 Construction of portable weeding cutter}

The construction features of the portable weeding cutter consists of the five following components: cutting blade, rotor head, protection cover, carrier pipe, connecting rod, operation handle, machine holder and engine as shown in Fig.(1).

\section{1-1-1-Cutting blades}

In this study, four shapes of cutting blades were used with portable weeding cutter. Two of them were imported blades, namely: 4-teeth and 8-teeth blades. However, the other two blades were modified blades, namely: short and long flying chain blades. The main specification and components of these are summarized in Table (1) and shown in Fig.(2-A, B, C and D). The 4-teeth and 8-teeth blades are a circular shape and made of treated steel. The 4 and 8 teeth are distributed on the outer circumference of each blade.

The modified blades consist of three main parts, namely: cylindrical case, case cover, and flying chain blades. Two lengths of flying chain blades were used in this study (short and long flying chain blades). The short 
one contains three triangular blades connected to each other by one link of chain plate to be flexible, as shown in Fig.(2-c). One end of the chain is fixed inside the cylindrical case, while other end with three blades and connected chain plates were left free outside of the case. However, the long flying chain contains five triangular blades connected each to other with links of chain plates. One end of the chain case is fixed inside the case while, the other end with five blades and connected chain plates were free outside of the case. The dimensions of the used chain plates were $44 \mathrm{~mm}$ in length and $12 \mathrm{~mm}$ in width. Two sets of short or long chain blades were fixed on the opposite side of the outer circumference of the cutting case. The cover case was provided with central hole to fix it with rotor head and 4 bolts to fix it with cutting cylindrical case.

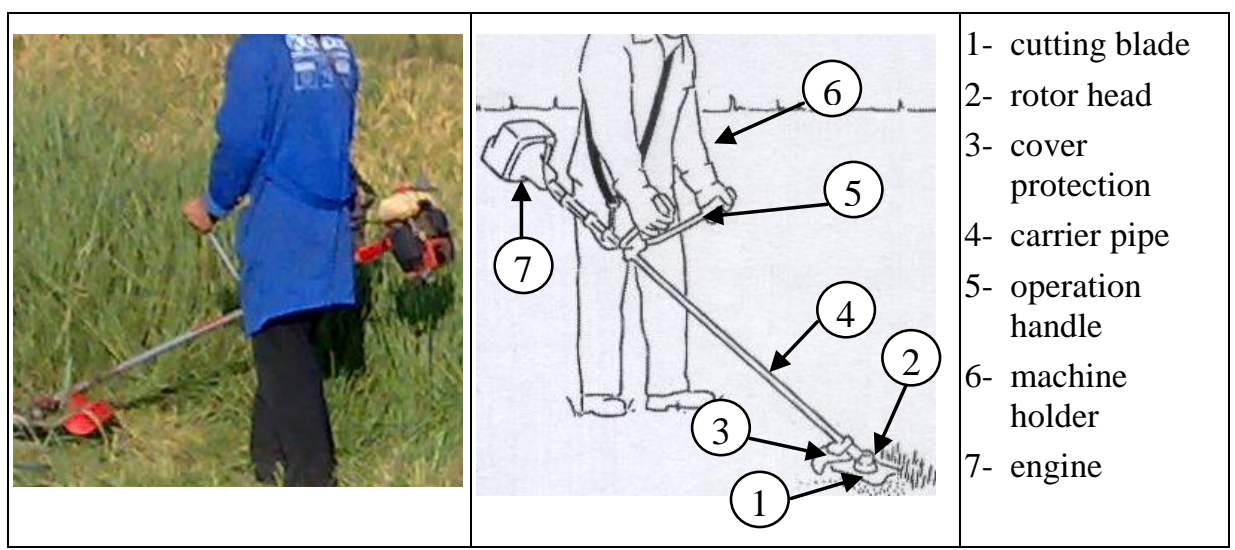

Fig. (1): General view and main components of portable weeding cutter.

Table:(1) The main specifications and components of cutting blades.

\begin{tabular}{|l|c|c|c|c|}
\hline & 4-teeh blade & 4-teeh blade & $\begin{array}{c}\text { Short flying chain } \\
\text { blades }\end{array}$ & $\begin{array}{c}\text { long flying chain } \\
\text { blades }\end{array}$ \\
\hline & & & & \\
\hline Tooth length, $\mathrm{mm}$ & 35 & 16 & 62 & 62 \\
\hline Tooth width, $\mathrm{mm}$ & 45 & 65 & 34 & 34 \\
\hline Working width, $\mathrm{mm}$ & 225 & 228 & 430 & 680 \\
\hline No of teeth/ blade & 4 teeth /blade & 8 teeth /blade & $\begin{array}{c}2 \text { chains } \times 3 \text { blades/ } \\
\text { chain }\end{array}$ & $\begin{array}{c}2 \text { chains } \times \\
5 \text { blades/ chain }\end{array}$ \\
\hline
\end{tabular}




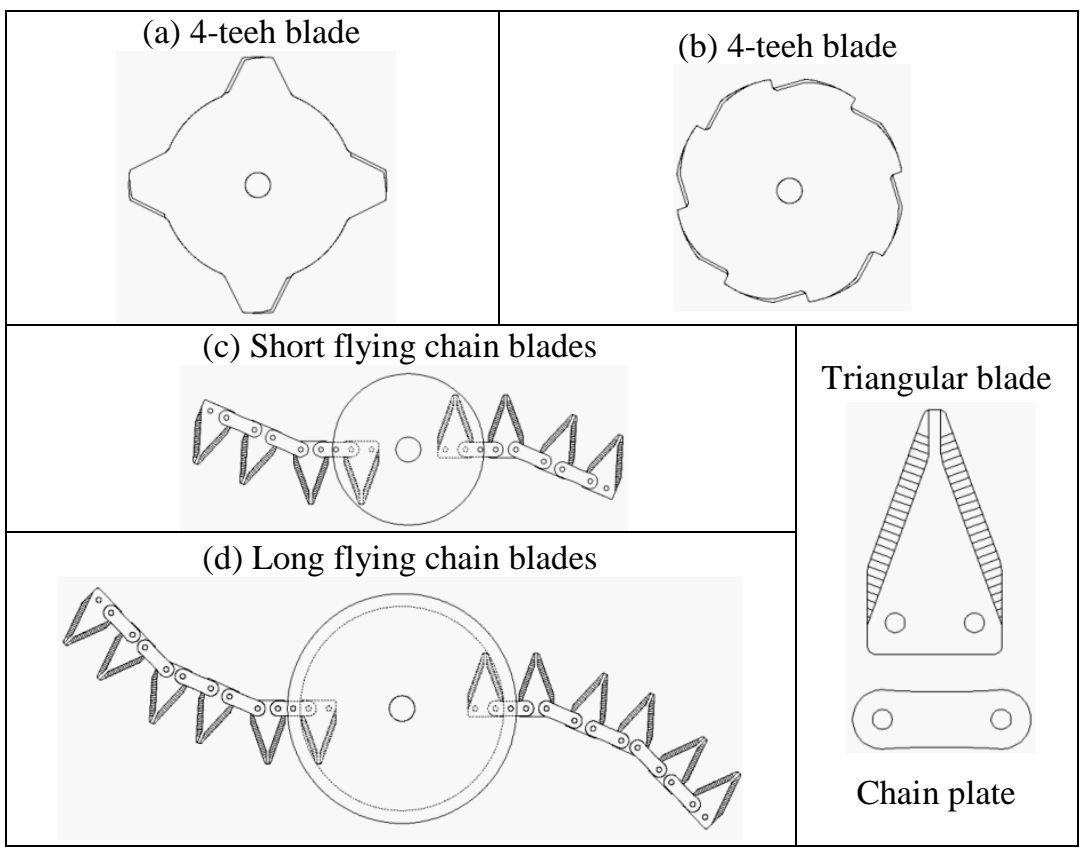

Fig. (2): The types and main components of cutting blades.

\section{1-1-2- Rotor head and cover protection.}

The end of weeding cutter is the rotor head which was equipped with special setting for fixing cutter blade. The cover protection was fixed on the carrier pipe behind the cutting blade on the rotor head as shown in Fig. (1).

\section{1-1-3- Carrier pipe and connecting rod}

The carrier was made from aluminum pipe with the length of $1500 \mathrm{~mm}$ and diameter $30 \mathrm{~mm}$. One of its ends was fixed with engine power output shaft through a centrifugal clutch and the other end fixed with rotor head. However, the connecting rod was passed through the carrier pipe and used to transmit the power between engine and rotor head which rotates the cutting blade.

\section{1-1-4- Operation handles and machine holder}

The operation handles were fixed on the carrier pipe to adjust the position of weeding cutter for cutting weeds. Also, the operation components of stop switch, throttle lever and starting throttle lever latch 
were fixed on the right hand. However, the machine holder was used to carry the machine on the worker's shoulder during cutting operation.

\section{1-1-5-Engine}

A small gasoline engine $0.7 \mathrm{~kW}$, two strokes, and air cooled with overall sizes (Length $\times$ Width $\times$ Height) $\mathrm{mm} 1810 \times 335 \times 320$ was used as the power source for operating portable weeding cutter.

\section{1-2- Cutting weeds using mechanical and manual methods}

The worker holds the weeding cutter on his shoulder, where the rotor head is off and is tilted about 20 degrees toward the sweep direction as shown in Fig. (3-a). The worker controls the rate of cutting speed depending on the material being cut. Heavy growth will require slower action than the light growth. The working starts by sweeping from his left to the right to avoid thrown debris, as shown in Fig. (3-b). During working with weeding cutter, the worker should avoid wire grass and dead/dry long-steam weeds from wrapping around the head shaft which can cause the clutch to slip resulting in damage to clutch system if repeated frequently. However, the manual cutting method was done using grass sickles. This sickle is a hand-held agricultural tool having a carved blade with sharp edge at one side used for cutting weeds and harvesting some crops. The labor catches the sickle by one of his hands while the other hand catches some of plants/hills of weed and starts to cut weeds by sickle as shown in Fig.(3-c).

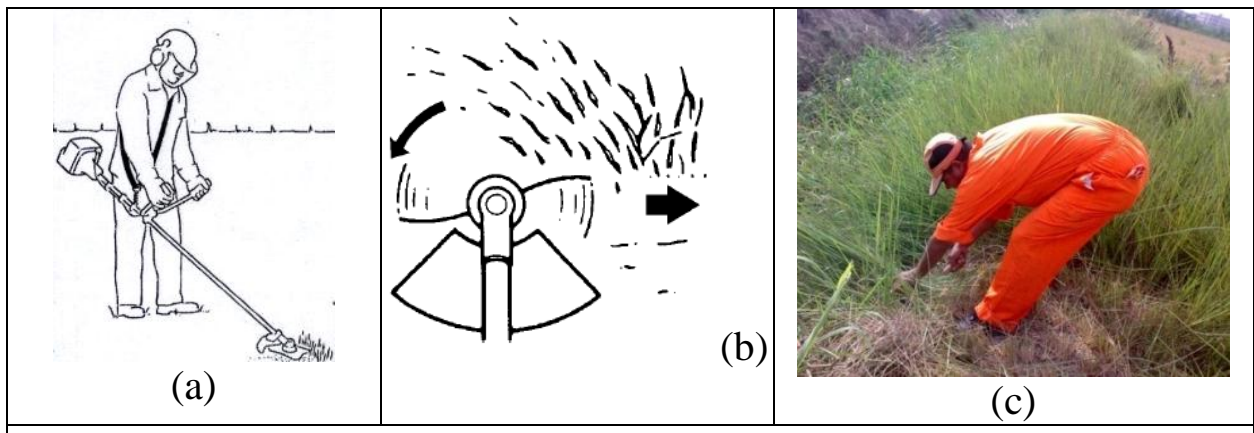

Fig. (3): Working method of portable weeding cutter and manual method.

\section{2-Performance evaluation}

The portable weeding cutter with two imported cutting blades and two modified cutting blades was evaluated for cutting three different types of 
weeds, namely: Diss grass (Ampelodesmos mauritanica), Giant reed (Arundo donax) and cogon grass (Imperata cylindrica). These types of weeds were selected as an example for the most common spreading weeds on the irrigation and drainage channel banks. Also, these types are different in physical and mechanical properties. The portable weeding cutter was evaluated based on the cutting height $(\mathrm{mm})$, cutting capacity, $\left(100 \mathrm{~m}^{2} / \mathrm{h}\right)$, the cutting efficiency (\%), energy requirement and weeding cost.

\section{3- Measurements}

\section{3-1- Physical and mechanical properties of weeds:}

Some physical properties such as plant/hill height, weed density and moisture content were measured. However the mechanical properties such as cutting force was measured during carrying out this investigation as the follows:

\section{a- Plant/hill height}

The heights of weed plants or hills for ten random samples were measured from white part of its root on soil surface to its upper end using steel measuring tape. The average values of plants or hills height and SD for each weed are summarized in Table (1).

\section{b- Weed density}

A wooden frame $\left(1 \mathrm{~m}^{2}\right)$ was used to determine the number of weed plants or weeds to calculate the weed density. Three random samples were repeated for each type of weed under study. The average values of weed density and SD for each weed are summarized in Table (1).

\section{c- Weed moisture content}

The weed moisture content was determined using an electric oven adjusted at $\left(60 \mathrm{c}^{\circ}\right)$ for 18 hours Jackson (1967). Weed samples were taken from weed places immediately before cutting process. The weed moisture content was calculated on dry bases using the following equation and the average values are recorded in Table (1):

$$
\text { Weed moisture content, } \%=\frac{M_{w}-M_{d}}{M_{d}} * 100
$$

Where: $\quad M_{W}=$ wet weed mass $(\mathrm{g})$; and

$M_{d}=$ dry weed mass $(\mathrm{g})$. 


\section{d- Cutting force}

The cutting force of one weed plant/hill was determined for each weed type under study at three levels from its root, namely: 5, 15 and 25 $\mathrm{cm}$, respectively. The cutting force of weed was measured using a Shimpo-Digital Force Gage, model FGN-50 (Japanese made) provided by cutting blade of grass sickle as shown in Fig. (4). Using the measuring instrument an incremental pull force was applied to the weed hill until cut.

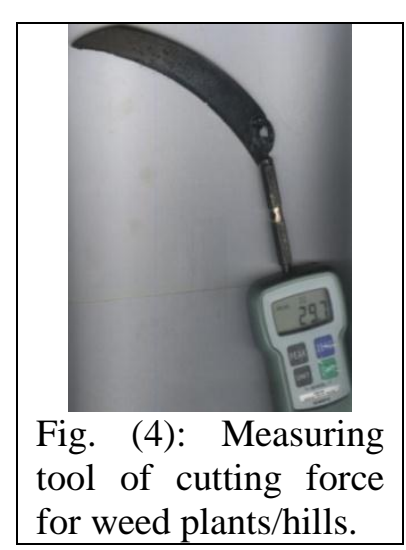

The recorded reading of cutting force, in Newton $(\mathrm{N})$ on the instrument screen was taken. The cutting force was determined for five random plants/hill of investigated weeds under study. The average values of cutting force and SD for each weed are summarized in Table (1).

Table (1): Some physical and mechanical properties of investigated weeds under study.

\begin{tabular}{|c|c|c|c|c|c|c|c|}
\hline \multirow{2}{*}{\multicolumn{2}{|c|}{ Items }} & \multicolumn{2}{|c|}{ Diss grass } & \multicolumn{2}{|c|}{ Giant reed } & \multicolumn{2}{|c|}{ Cogon grass } \\
\hline & & Av. & SD & Av. & $\mathrm{SD}$ & Av. & SD \\
\hline \multicolumn{2}{|c|}{ Plant height, $\mathrm{cm}$} & 256.00 & 20.74 & 162.60 & 17.36 & 86.67 & 14.71 \\
\hline \multicolumn{2}{|c|}{ Plant(hill) Density $/ \mathrm{m}^{2}$} & 8.89 & 3.02 & 31.63 & 8.83 & 9.86 & 3.67 \\
\hline \multicolumn{2}{|c|}{ Moisture content, \% } & \multicolumn{2}{|c|}{80.59} & \multicolumn{2}{|c|}{71.21} & \multicolumn{2}{|c|}{59.57} \\
\hline \multirow{4}{*}{$\begin{array}{l}\text { Cutting } \\
\text { force, } \mathrm{N}\end{array}$} & at $5 \mathrm{~cm}$ & 40.71 & 5.50 & 123.96 & 38.34 & 97.86 & 28.61 \\
\hline & at $15 \mathrm{~cm}$ & 28.17 & 4.66 & 55.21 & 16.33 & 39.84 & 10.97 \\
\hline & at $25 \mathrm{~cm}$ & 5.49 & 3.04 & 27.58 & 7.87 & 27.02 & 18.50 \\
\hline & Average & 24.79 & 4.40 & 68.91 & 20.85 & 54.91 & 19.63 \\
\hline
\end{tabular}

\section{3-2- Cutting height}

The cutting height for each type of weed plants or hills were measured after cutting operation using different cutting blades and manual cutting method. The cutting heights were measured for remaining parts of weed plant/hills from soil surface.

\section{3-3- Weeding cutter capacity}

The actual cutting capacity of weeding cutter with different cutting blades under study was calculated by measuring the time spent for cutting $1 \mathrm{~m}^{2}$ of any given type of weed under study comparing with 
manual cutting methods. The cutting capacity was calculated as follows:

$$
\text { Cutting capacity, } m^{2} / h=\frac{\text { cutting area, } m^{2}}{\text { cutting time, } h}
$$

\section{3-4- Cutting efficiency}

A wooden frame of $1 \mathrm{~m}^{2}$ was used to determine the quantity of standing weeds before and after cutting treatments. The dry weight of weed was determined by drying the collected weeds using an electric oven adjusted at 60 for 18 hours (Jackson, 1967). The cutting efficiency of each blade under study was calculated using the following equation.

Cutting efficiency, $\%=\frac{D_{w b}-D_{w a}}{D_{w b}}$

Where: $\quad D_{w b}=$ is the dry mass ( $\mathrm{g}$ ) of weeds immediately before cutting operation $/ \mathrm{m}^{2}$.

$D_{w a}=$ is the dry mass $(\mathrm{g})$ remaining without cutting immediately after cutting operation in $1 \mathrm{~m}^{2}$.

\section{3-5- Weeding energy requirement}

The total energy requirement for cutting investigated weed under study using portable weeding cutter, including the manual and mechanical energy inputs, were calculated as the follows:

Total energy requirements, $k W \cdot h / m^{2}=\frac{\text { Manual energy input, } k W+\text { Mechanical energy input, } k W}{\text { Weeder capacity, } 100 \mathrm{~m}^{2} / \mathrm{h}}$

The manual energy input was calculated using the following formula according to Norman (1978):

$$
E_{M m}=0.75 \times 0.28 T_{a}
$$

Where: $\quad E_{M m}=$ Male manual energy input, $\mathrm{MJ}$;

$0.75=$ Energy input of an average adult male, $\mathrm{MJ} / \mathrm{h}$ and 0.28 factor for converting units to $\mathrm{kW}$; and

$T_{a}=$ Useful time spent by male worker per unit operation, $\mathrm{h}$.

However, the mechanical energy input was calculated using the following formula according to Pimentel, (1992):

$$
E_{g f}=42.3 \times 0.28 P
$$

Where: $\quad E_{g f}=$ Liquid fuel energy input for gasoline, MJ; 


\section{3 = average energy value of gasoline $\mathrm{MJ} / \mathrm{L}$ and 0.28 factor for converting units to $\mathrm{kW}$; and \\ $P=$ Amount of gasoline consumed per hour, $\mathrm{L} / \mathrm{h}$}

\section{3-6- Weeding estimation cost}

The manual and mechanical weeding costs were analyzed to shows the economical objective of this investigation. The manual weeding cost was determined by calculating the average of man.hour $/ 100 \mathrm{~m}^{2}$ required to perform the weed cutting operation based on 30 LE/day labor cost, (8 hours / day) as follows:

The total weeding cost $L E / \mathrm{m}^{2}=$ man. hour $/ 100 \mathrm{~m}^{2} \times$ labor cost, However, the mechanical weeding cost using the portable weeding cutter with different blades under study included the fixed, variable and total cost LE/h and LE/100 $\mathrm{m}^{2}$, calculated as follows:

The total mechanical weeding cost $(L E / h)=$ Fixed cost + Variable cost The total mechanical weeding $\operatorname{cost}\left(L E / 100 \mathrm{~m}^{2}\right)=\frac{\text { Total cost }, L E / h}{\text { Weeder capacity, } 100 \mathrm{~m}^{2} / \mathrm{h}}$

The annual capital cost which include the depreciation and interest costs was estimated at $25 \%$ of the machine cost. The remaining annual elements of fixed costs (taxes and housing) were annual assumed to be 2\% of the machine price according Hunt (1983). The fixed cost, LE/h could be determined with assumption of machine life expectancy 5 years, 500 operating hour per year and the modified portable weeding cutter price of 1200 LE. However, the machine variable costs which included the cost of labor, fuel and oil consumption, repair and maintenance were calculated based on one labor required to operate portable weeding cutter, 30 LE/day ( 8 hour/day). The fuel consumption cost was determined to be $0.9 \mathrm{LE} / \mathrm{l}$. and the oil cost calculated based on the oil consumption about $30 \%$ of fuel cost. The cost of repair and maintenance was estimated at $2 \%$ of the machine cost per 100 hours of operation.

\section{RESULTS AND DISCUSSION}

\section{1- Cutting height}

The obtained results of cutting height using different cutting blades with weeding cutter compared with manual cutting method for cutting weeds under study are summarized in Table (3). These results indicated that the 
cutting height values varied between using different mechanical and manual methods for cutting weeds. The manual cutting method gave the lowest values of cutting height followed by that obtained by short flying chin blades and 4-teeth blade. On the other side, the short flying chain blades gave the maximum uniformity in cutting height than that obtained with other blades of 4- teeth, 8-teeth and the long flying chain blades.

Table (3): The cutting height affected by using mechanical and manual cutting methods.

\begin{tabular}{|l|c|c|c|c|c|c|c|c|c|c|}
\hline & \multicolumn{2}{|c|}{$\begin{array}{c}\text { A- } 4 \text { teeth } \\
\text { blade }\end{array}$} & \multicolumn{2}{c|}{$\begin{array}{c}\text { B- } 8 \text { teeth } \\
\text { blade }\end{array}$} & \multicolumn{2}{c|}{$\begin{array}{c}\text { C-Short } \\
\text { flying chain } \\
\text { blades }\end{array}$} & \multicolumn{2}{c|}{$\begin{array}{c}\text { D- Long } \\
\text { chain flying } \\
\text { blades }\end{array}$} & \multicolumn{2}{|c|}{$\begin{array}{c}\text { Manual } \\
\text { method }\end{array}$} \\
\hline & Av. & SD & Av. & SD & Av. & SD & Av. & SD & Av. & SD \\
\hline Cogon grass & $\mathbf{1 3 . 2 3}$ & 4.91 & $\mathbf{1 5 . 0 2}$ & 6.83 & $\mathbf{1 1 . 2 9}$ & 3.86 & $\mathbf{1 7 . 2 2}$ & 8.93 & $\mathbf{9 . 1 8}$ & 2.88 \\
\hline Diss grass & $\mathbf{1 9 . 2 8}$ & 6.07 & $\mathbf{2 3 . 2 0}$ & 8.11 & $\mathbf{1 6 . 2 0}$ & 4.66 & $\mathbf{2 7 . 2 0}$ & 9.65 & $\mathbf{1 4 . 7 8}$ & 3.63 \\
\hline Giant reed & $\mathbf{2 8 . 5 3}$ & 7.40 & $\mathbf{3 3 . 4 1}$ & 8.77 & $\mathbf{2 3 . 2 0}$ & 4.76 & $\mathbf{3 9 . 2 0}$ & 10.67 & $\mathbf{1 9 . 4 9}$ & 3.93 \\
\hline
\end{tabular}

\section{2- Weeding cutter capacity}

The average values of weeding cutter capacity $\mathrm{m}^{2} / \mathrm{h}$ for cutting the weeds of diss grass, giant reed and cogon grass which are growing on the irrigation and drainage channel banks with mechanical method compared with manual cutting method are illustrated in Fig. (5). The obtained results indicated that the maximum capacities of portable weeding cutter of $149.82,120.32$ and $44.56 \mathrm{~m}^{2} / \mathrm{h}$ were obtained using the short flying chain blade for cutting diss grass, giant reed and cogon grass, respectively. However using 4-teeth blade gave the next highest values of capacity followed by 8-teeth blade and long flying chain blades. Meanwhile, using manual cutting gave the lowest values of cutting weed capacity with respect to the mechanical cutting capacity using any given cutter blade under study.

These results mean that the manual cutting capacity was increased from 34.96 to $149.82 \%$ from 26.26 to $120.32 \%$ and from 25.53 to $114.56 \%$ for cutting diss grass, giant reed and cogon grass, respectively when using the modified cutting blades of short flying chain with portable weeding cutter. On the other hand using the portable weeding cutter with short flying chain blades increased the cutting capacity comparing with 
manual method by about $328.55,358.19$ and $348.73 \%$ for cutting diss grass, giant reed and cogon grass, respectively. However, the increment percentages in cutting capacity using the short modified flying chain blades with portable weeding cutter instead of 4-teeth blade were 34.13, 30.54 and $26.66 \%$ and were $49.30,40.17$ and $45.01 \%$ with 8 -teeth blade for cutting diss grass, giant reed and cogon grass, respectively. These results concluded that the modified short flying blades with portable weeding cutter gave the best results of cutting capacity in comparison with other cutter blades and manual cutting method for cutting common growing weeds of diss grass, giant reed and cogon reed on irrigation and drainage borders.

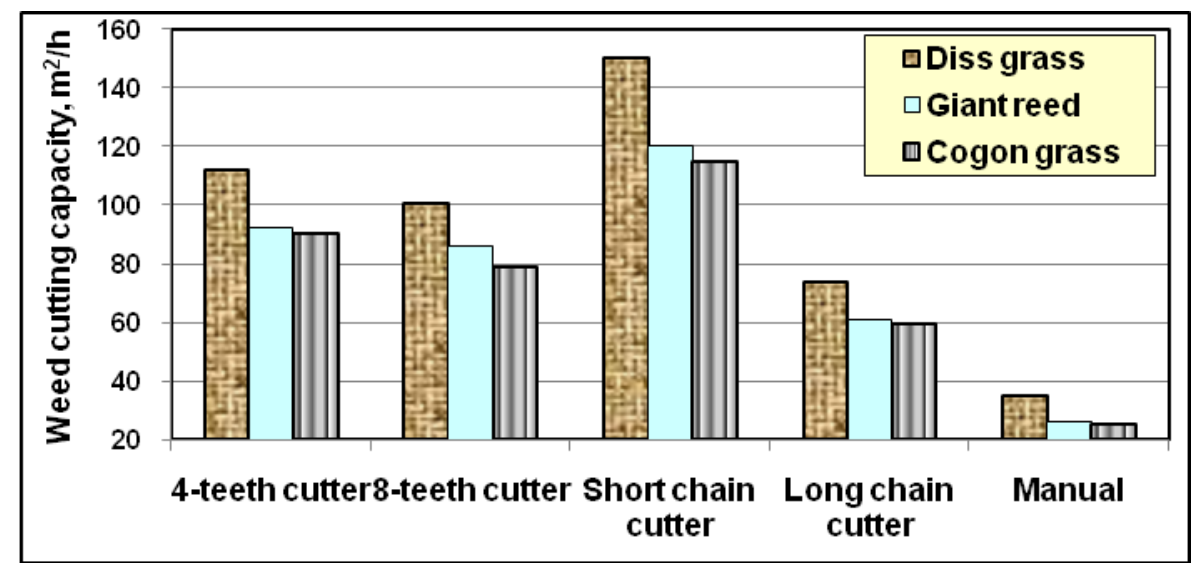

Fig.(5): Weeds cutting capacity using mechanical and manual methods.

Regarding the effect of weed type on the cutting capacity, the results indicated that the maximum cutting capacity was obtained for diss grass followed by giant reed and cogon grass using blade under study. The average values of cutting capacity were $149.82,120.32$ and $114.56 \mathrm{~m}^{2} / \mathrm{h}$ using the modified short flying chain blades with portable weeding cutter comparing with $34.96,26.26$ and $25.53 \mathrm{~m}^{2} / \mathrm{h}$ using manual method for cutting diss grass, giant reed and cogon grass, respectively. These result may be due to the variance in physical and mechanical properties of each weed type.

\section{3- Cutting efficiency}

The average value of cutting efficiency using any given cutter blade under study with portable weeding cutter for cutting the growing weeds 
of diss grass, giant reed and cogon grass on channel banks and borders comparing with manual cutting method are illustrated in Fig. (6). The results show that the cutting efficiency of using the modified short flying chain blades with portable weeding cutter gave the highest values of cutting efficiency with respect to the other cutting blades used for cutting any given weed type under study. The next highest average values of cutting efficiency were obtained with using 4-teeth cutter blade followed by 8 -teeth cutter blade for cutting any given weed type under study. However, the average values of cutting efficiency for manual method were found to be lower than that obtained with using the modified short flying chain blades and higher than that obtained with using 8-teeth and long flying chain blades for cutting any given weed type under study.

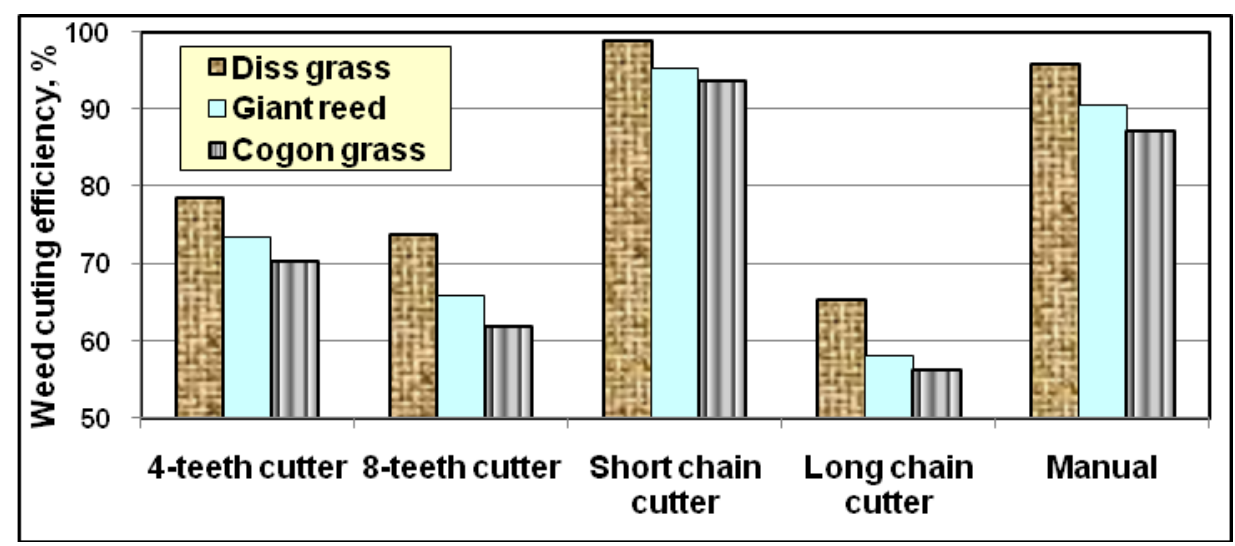

Fig.(6): Weed cutting efficiency using mechanical and manual methods.

The maximum efficiencies of $98.87,95.32$ and $93.65 \%$ were obtained using modified short flying chain blades compared with 95.90, 90.55 and $87.09 \%$ using cutting manual method for cutting diss grass, giant reed and cogon grass, respectively. The increment percentages in cutting efficiency due to using the modified short flying chain blades were 25.79, $34.23,51.52$ and $3.09 \%$ comparing with 4-teeth blade, 8 teeth blade, modified long flying chain blades and manual method, respectively for cutting diss grass weeds. The corresponding increment percentages in cutting efficiency for cutting giant reed weeds were 29.87, 44.93, 64.39 and $5.26 \%$, respectively. Also, they were 33.33, 51.52, 71.23 and $66.67 \%$ for cutting cogon grass weeds with using 4-teeth blade, 8-teeth blade, modified long flying chain blades and manual method, 
respectively. The results also indicated that the highest values of the cutting efficiency were obtained for cutting diss grass weeds using any given cutting blades under study. However, the lowest values of cutting efficiency were obtained for cutting cogon grass weeds using any given cutting blades under study.

\section{4- Energy requirement}

The energy requirement for cutting weeds on irrigation and drainage channel banks using mechanical method with different cutting blades under study in comparison of manual cutting method are calculated per $100 \mathrm{~m}^{2}$ and summarized in Table (4). These results showed that the energy requirement values varied between mechanical methods using different cutting blades and manual cutting method. The lowest value of energy requirement was obtained using modified short chain blades for cutting any given weed under study, followed by cutting with manual method.

Table (4) : Energy requirement $\left(\mathrm{kW} . \mathrm{h} / 100 \mathrm{~m}^{2}\right)$ for cutting weeds using mechanical and manual method.

\begin{tabular}{|c|c|c|c|c|c|}
\hline & \multicolumn{4}{|c|}{ Mechanical method } & \multirow[b]{2}{*}{$\begin{array}{l}\text { Manual } \\
\text { method }\end{array}$} \\
\hline & $\begin{array}{l}\text { 4-teeh } \\
\text { blade }\end{array}$ & $\begin{array}{l}\text { 4-teeh } \\
\text { blade }\end{array}$ & $\begin{array}{c}\text { Short flying } \\
\text { chain } \\
\text { blades }\end{array}$ & $\begin{array}{l}\text { long flying } \\
\text { chain } \\
\text { blades }\end{array}$ & \\
\hline Diss grass & 0.783 & 0.901 & 0.543 & 1.190 & 0.601 \\
\hline Giant reed & 1.005 & 1.117 & 0.716 & 1.536 & 0.800 \\
\hline Cogon grass & 1.060 & 1.266 & 0.783 & 1.637 & 0.823 \\
\hline
\end{tabular}

The energy requirement using the modified flying chain blades decreased by about 44.98, 65.91, 119.07 and $10.55 \%$ comparing with 4-teeth blade, 8 teeth blade, long flying chain blades and manual method, respectively for cutting diss grass. However, the corresponding values in the decrement percentage of energy requirement for giant reed were about $40.41,56.07,114.50$ and $11.70 \%$. Also, they were 36.36, 61.67, 109.07 and $5.06 \%$ for cutting cogon grass with 4-teeth blade, 8-teeth blade and modified long chain blades, respectively. These results mean that using modified short flying chain blades can save the energy requirement by about 5-11, 36-44, and 56-65\% with respect to manual method, 4-teeth 
blade and 8-teeth blade, respectively for cutting common growing weeds on irrigation and drainage channel banks.

\section{5- Estimation of weeding cost}

The average values of cost estimation (LE/h) of cutting growing weeds on irrigation and drainage channel banks, using portable weeding cutter with any given cutting blades comparing to manual cutting method, were 4.71 and $3.75 \mathrm{LE} / \mathrm{h}$, respectively. However, the weeding cost (LE/100 $\mathrm{m}^{2}$ ) using portable weeding cutter with 4-teeth, 8-teeth, short flying chain and long flying chain blade were 4.21, 4.69, 3.14 and $6.36 \mathrm{LE} / 100 \mathrm{~m}^{2}$ respectively, comparing with $10.73 \mathrm{LE} / 100 \mathrm{~m}^{2}$ using manual cutting method for cutting diss grass. However, the corresponding value of weed cost for cutting giant reed were 5.11, 5.48, 3.91, 7.75 and 14.28 LE/100 $\mathrm{m}^{2}$. Also, costs were 5.20, 5.96, 4.11, 7.92 and $14.69 \mathrm{LE} / 100 \mathrm{~m}^{2}$ for cutting cogon grass using 4-teeth, 8-teeth, short flying chain and long flying chain blades, respectively. These results concluded that the modified short flying chain blades reduce the weeding cost by about 240$265 \%$ for manual cutting method.

\section{Conclusion}

Using the portable weeding cutter with short flying chain blades increased the cutting capacity by about $328.55,358.19$ and $348.73 \%$ and increased cutting efficiency by about 3.09, 5.26 and $7.53 \%$ comparing with manual method for cutting diss grass, giant reed and cogon grass, respectively.

The introduction of the portable weeding cutter with short flying chain blades for controlling growing weeds on the irrigation and drainage channels banks should be promoted in order to reduce the manpower requirements (about 5-11\%) and reduce the weeding cost (about 240-265\%) that is not easily available and also to be able to perform weeding operation in the best period of cutting weed.

Using portable weeding cutter with short flying chain blades reduce the blade damage and the bad reactions resulted from shocks with hard things in working area. However, the continuous working could 
cause certain amount of fatigue of the workers, and should be taken into consideration in future study.

\section{REFERENCE}

Bennett, D. (2006). Cogon grass, deep-rooted sedge in Mississippi Delta. Delta Farm Press news story: 16-23.

Burnell, K.D. ; J.D. Byrd, ; Jr.G. Ervin; P.D. Meints; J.W.Jr. Barnett and D. B. Mask (2003b). Mowing and cultural tactics for cogon grass [Imperata cylindrica (L.) Beauv.]. Proc. South. Weed Sci. Soc. 56:353.

Charles, G.; A. Sullivan; I. Christiansen and G. Roberts (2002). Managing Weeds on Roads, Channels and Water Storages. A guide for integrated management of weeds in cotton, section F3. (NSW Agriculture, QDPI, QDPI \& CSIRO) -F3.1- F3.8 Pages.

Chikoye, D. ; V.M. Manyong and F. Ekeleme. (2000). Characteristics of spear grass (Imperata cylindrica) dominated fields in West Africa: crops, soil properties, Farmer perceptions and management strategies. Crop Protect. 19: 481-487

Coffman, G. ; P. Rundel and R. Ambrose (2004). Invasion of Arundo donax in river ecosystems of Mediterranean-climate regions: Causes, impacts and management strategies. Ecological Society of America Annual Conference, 1-4 Aug 2004, Portland, Oregon: 3239.

Fogelberg F. and G. Kritz (1999). Intra-row weeding with brushes on vertical axes-factors influencing in-row soil height. Soil and Tillage Research, 50: 149-157.

Hanson, E. (1996). Tools and techniques. Chapter 3 in Invasive plants. J.M. Randall and M. Marinelli, eds. Handbook \#149. Brooklyn Botanical Garden, Inc., Brooklyn, New York: 111 pgs.

Hunt, D. (1983). Farm power and machinery management. $8^{\text {th }}$ ed. Iowa State Univ. Press. Ames, Iowa, USA : 86-107.

Jackson, M. L., (1967). Soil chemical analysis. Perntic-Hall, India. Private LTD. N. , Delhi, India: 71-85.

Johnson, E.R.R.L.; J.F. Gaffney, and D.G. Shilling (1999). The influence of discing on the efficacy of imazapyr for cogon grass. Control. Proc. South. Weed Sci. Soc . 52:165 
Mgidi, T. (2004). An assessment of invasion potential of invasive alien plant species in South Africa, CSIR-Environmental, Pretoria, South Africa : 13-21.

Norman, M. J. T. (1978). Energy inputs of substance cropping systems in the tropics, agro-Ecosystems, 4: 355-366.

Pimentel, D. (1992). Energy inputs in production agriculture. Energy in farm production, Elsevier, and Amsterdam. P: 13-29.

Swearingen, J. (2009). Weed US Database of Plants Invading Natural Areas in the United States: Giant Reed (Arundo donax). http://www.invasive.org/weedus/subject.html, ( 12-9-2011).

Van Wilgen, B.W.; J.L. Nel and M. Rouget (2007). Invasive alien plants and South African rivers: A proposed approach to the prioritization of control operations. Freshwater Biology 52:711723.

Wiley Online Library (2000). Journal of Ecology Volume: 88, Issue: 3, Pages: 479-491. ISSN: 13652745. onlinelibrary.wiley.com, (12-92011).

$$
\begin{aligned}
& \text { الملخص العربيى } \\
& \text { تطوير آلة محمولة بقرص قاطع لمقاومة حشائش حواف الترع والمصارف } \\
& \text { وائل فتحى المتولى بّ ـ محمود السيد العراقى؛ } \\
& \text { ب باحث - معهد بحوث الهنسة الزراعية ـ مركز البحوث الزراعية } \\
& \text { ؛ باحث أول ـ معهُ بحوث الهندسة الزراعية ـ مركز البحوث الزراعية الزية }
\end{aligned}
$$


أجريت عمليات التطوير والتصنيع لأداة القطع بإحدى ورش القطاع الخاص بينما أجريت

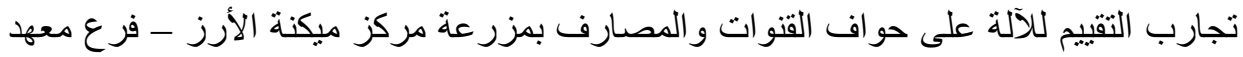

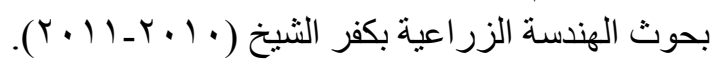

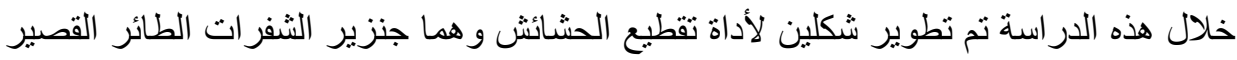

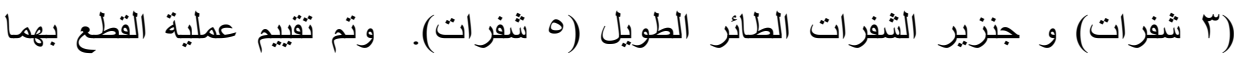

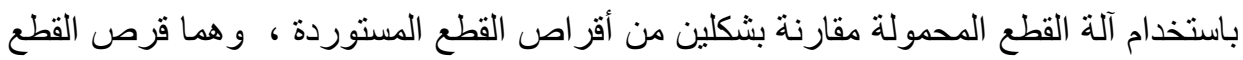

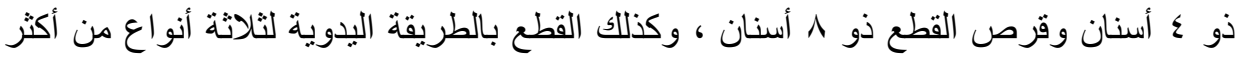

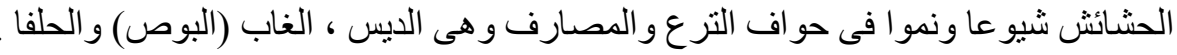

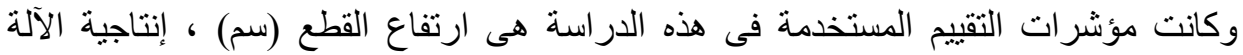

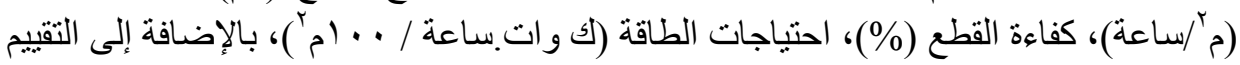

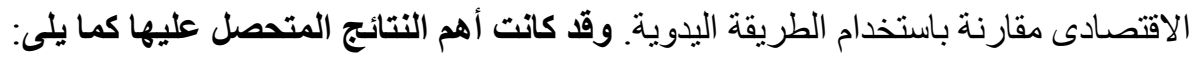

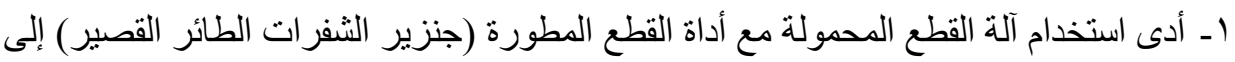

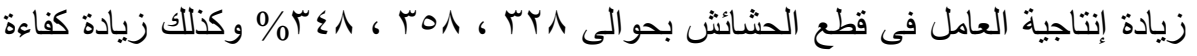

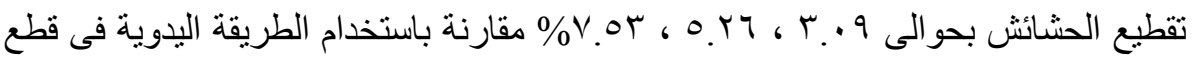

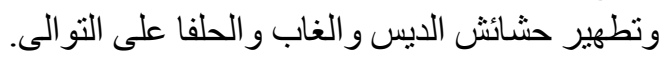

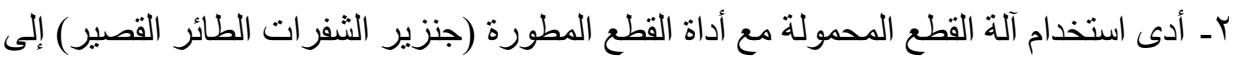

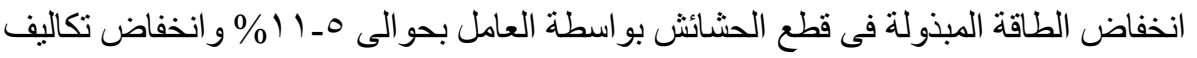

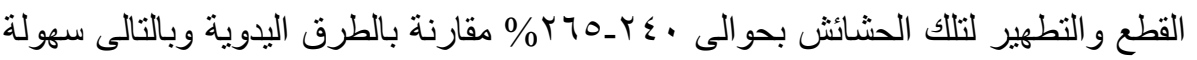

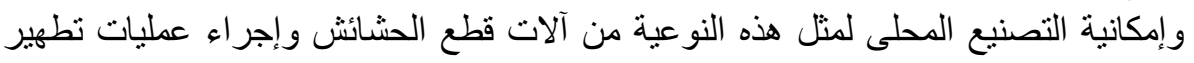

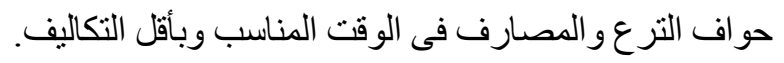

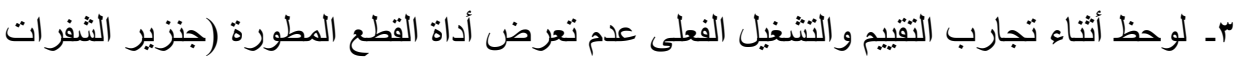

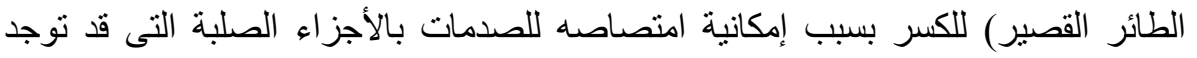

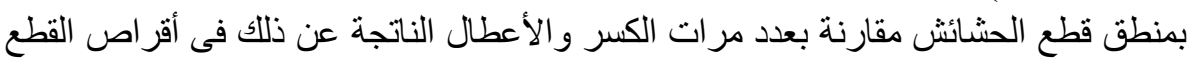

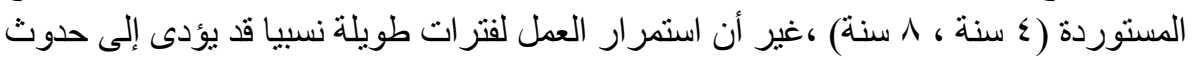

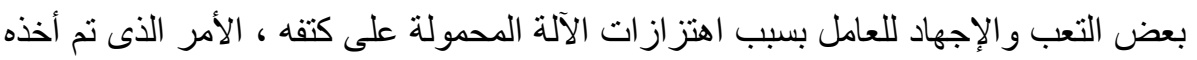
فى الاعتبار فى در اسة أخرى قادمة. لإعل 